\title{
The Philosophy of Technology and Engineering
}

\author{
Durmuş Günay
}

Maltepe University, Faculty of Engineering and Natural Sciences, Department of Industrial Engineering, 34857 Maltepe- Istanbul, Turkey.

\begin{abstract}
In this study, first, we will address the meaning of engineering, engineer and technology. The purpose here is to clarify these concepts and show the relationships between them. Technology has always been a difficult concept to understand and express exactly what it is. To understand easily what technology is, in this study, we consider the substance concept of the philosophy of Aristotle, we will try to put forward a new explanation style. In other words, we will try to present a technology philosophy based on Aristotle's philosophy and also its relation with the engineering science. Secondly, we will look at the history of engineering in the contexts of the technological development. Lastly, we will also address the new trends and approaches in the engineering education in the world at the beginning of the $21^{\text {st }}$ century and today. Since engineering education is also being transformed in accordance with the possibilities brought about by technology in the education field and the needs and demands of society.
\end{abstract}

Keywords: Philosophy of Technology; Technology; Engineering; Engineering Education

\section{Teknoloji ve Mühendislik Felsefesi}

\begin{abstract}
Özet
Bu çalıșmada, öncelikle; mühendislik, mühendis ve teknolojinin anlamı dile getirilecektir. Amacımız bu kavramların anlamlarını açıklığa kavușturmak ve aralarındaki ilişkileri göstermektir. Teknolojinin ne olduğunun anlatılması ve anlaşılması daima zor olmuştıur. Teknolojinin ne olduğunu kolayca anlaşılır kılmak için, Aristoteles felsefesindeki cevher kavramını gözönüne alarak, yeni bir açılkama tarzı ortaya koyacağız. Bir başka ifade ile Aristoteles felsefesine dayalı olarak ve mühendislik ve malzeme ilişkisini de gözönüne alarak, teknoloji felsefesini sunmaya çalışacağız. İkinci olarak, teknolojinin gelişimi bağlamında, kısaca, mühendislik tarihine de bakacağız. Son olarak, 21. yüzyılın başında ve günümüzde, Dünyada mühendislik eğitimindeki yaklaşımlara ve yeni eğilimlere değineceğiz. Çünkü, mühendislik eğitimi; toplumun ihtiyaçları ve istekleri ile teknolojinin eğitim alanında getirdiği imkanlara göre dönüşmektedir.
\end{abstract}

Keywords: Teknoloji Felsefesi; Teknoloji; Mühendislik; Mühendislik Eğitimi

\section{INTRODUCTION}

Since the 1980s, the dynamics like technology, globalization and competition have profoundly affected all areas of life as well as higher education. In particular, information and communication technologies have created new opportunities and facilities like internet and distance education, especially in the field of higher education. Globalization has enhanced and expanded the impacts of technology like how technology has been influenced by both globalization and competition. As a result of these developments, developed countries undergo the stages of knowledge-based economy and knowledge-society. A virtual world has been created by the internet and information technologies have expanded the boundaries against the real world. Our world perception, imagination of

*Yazışma Adresi / Address for Correspondence:

Durmuş Günay, Email: dgunay@hotmail.com

Geliş Tarihi / Received Date: 26.12.2017

Kabul Tarihi / Accepted Date: 10.01.2018

Doi: $10.26701 /$ uad.371662 the world and the perception of being (ontos) changed in a way that can never come back in our mind. When the perception of ontos changed, the epistemic system, information system and education system, which are all based on the ontos perception, were also inevitably changed and transformed. These developments led to an expansion in higher education and the coming out of new phenomena such as mobility, diversification, differentiation and internationalization in the higher education area. Competitiveness of a society has been measured using globally valid scales with the capacity of producing knowledge and technology and the ability of human cultivation. Criteria and measurements based on international scales have become more important.

Engineering education is also being transformed in accordance with the possibilities brought about by technology in the education field and the needs and demands of society. New multi-disciplinary and inter-disciplinary programs have been born. In addition to the core engineering education, general education, general and speci- 
alized competences have gained importance. Creativity, innovation and entrepreneurship have also gained more significance. The worlds of market and education have become integrated with each other.

The relations between market and university, the boundaries of competition in higher education, ethical values and the student view as a customer are on the agenda of discussion in the world today. Engineering education also plays a critical role for the nation's prosperity.

\section{ENGINEERING AND THE ENGINEER}

Engineering is the practical application of scientific principles in a creative way to design, develop, carry out and build structures, machines, equipment/tools, manufacturing processes and/or intended functions under the specified conditions, economically and safely. The main characteristics of engineering are science, mathematics and design. Engineering is a form of problem solving. Engineering covers the technology related with the engineering area and engineering science.

One who practices engineering is called an engineer. Engineers design and produce tools and mechanisms and aspire for their products to work faster while becoming more economical. They are problem solvers and creative people. Engineers concurrently work in three worlds: The virtual world that involves the scientific principles and ideas, intangible world where ideas are transformed into specific projects and intellectual properties, and the tangible or external world where projects are turned into physical products. Engineers firstly transform their ideas into designs by using scientific principles and mathematics, then put them into words by creating feasible projects and lastly manufacturing them by using technology. Thus, they carry them into the world of reality.

Transformation of projected ideas to the external or real world takes place through technology. Thus, ideas and designs emerge in the external world as physical objects (technological products). Engineers carry out a process in the form of ideas, design and product. The materials are inserted into a designed form with scientific principles and then the engineering/technological product emerges. Theodore Von Karman (1881-1963) observed that "scientists discover the real world, engineers create a world that does not exist ever before". Engineers make artificial objects for living in a better society. An engineer has one foot in the world of facts (physical world) and has another foot in the world of imagination (world of mind).

Substantially, an engineering study adds artificial objects (artifacts) to our world. Concepts of man-made (artificial) objects come first from the objects. Artifacts first exist in engineers' mind, then they are expressed as a project (design), after that they come into the world as a product.

The word "engineer" stems from the verb of "to engine". The words "engine" and "ingenious" are derived from the
Latin root, "ingenerate" and it means "to create" (Adams, 1995). "To create" does not mean making something out of nothing without its instance and object. It means creating something from an other thing that previously existed in a different form. In old English, the verb "engine" meant that of invention. The concept of "engine" includes the meanings of both "to create" (this meaning derives from its Latin root) and "invention" (this meaning comes from the English language). Therefore, old "engineers" were the creative people who invented new things. In contemporary English, the word "engine" as a noun simply means engine, machine or locomotive. In English speaking countries, it is generally accepted that it is not enough for an engineer to be creative, engineers must also drive trains, operate power plants and understand how to fly planes. The meaning of a concept is closely related to the path that it follows along history. If a river as a whole are the flow that take place between its source and sea, a concept emerges as a result of the combination of the meanings that it acquires throughout history.

The term "engineer" in Turkish originated from the Persian verb of Andaâhten or Andazidan, which meant "drawing" in early times, and later it gained the meaning of "measuring". The noun "Andaze", which has the meaning of size, measurement and also geometry, derives from the same Persian verb root. Arabs bring the letter of " $h$ " to the front of the word "Andaze" and use it as "hende$s e$ ". They derived the engineer word from the word of the Hendese. Arabs also gave the name "el-mühendis" to the people who dealt with geometry (Ibn Manzur).

With the "Industrial Revolution" (1760-1830), the world witnessed a great transformation in the UK economy during the end of $18^{\text {th }}$ century and the beginning of the $19^{\text {th }}$ century. Before the industrial revolution, the economy was based on mostly farming. Transportation was poor. Workers were making products in their homes. The invention of the multiple-spindle spinning machine in 1763, the water-powered spinning machine in 1771 and other mechanical devices gave rise to emergence of factory systems and the need of mechanical power. Watt invented the steam engine in 1765 and with the use of the steam engine in the cotton, coal mining and steel industry, the UK gained advantage in production and trade. Moreover, the productivity of UK workers had increased. In the USA, however, such development did not occur until 1850 (Gimpel, 1997; Basalla, 1996).

The history of mechanical engineering in the ancient world traced back to the inventors or designers of the mechanisms that worked with man or animal power, wind or water energy, or a combination of them (Londels, 2000).

Engineering applications such as flight, irrigation, construction has had completely peaceful applications; however at the beginning, the term "engineer" had been used to mean "military engineer" because the term "engineer" derived from the term "engines of war". Engines of war 
were composed of constructions such as catapults, floating bridges, and war towers. Invention of the steam machine in the second half of the $18^{\text {th }}$ century was the major force that gave rise to the industrial revolution. Steam machines also gave momentum to the development of all kinds of other machines. The engineering society, who dealt with devices and machines, gradually emerged and USA officially recognized mechanical engineering in 1847 (Adams, 1995).

The invention of the steam machine led to the industrial revolution and with the invention of steam engine, power generated machines replaced other devices. After the IT revolution, computers began to make ways between the muscle and power generated machines. After the IT revolution, muscle powered machines gave way to power generated machines controlled by computers. Nowadays, mechanical engineers mainly deal with computer aided engineering. Computer aided engineering is also used in the development of new technologies and materials. Commitment to the development of machines, processes, and equipment that are environment friendly that produce less pollution is another growing field in mechanical engineering. Mechanical engineers seldom work independently on small projects; most of them work in multi-disciplined, major projects in collaboration with other fields.

In every aspect of our modern life, from air conditioned houses to industrial plants to transportation, we can see the engineer's contribution. Engineers are working to develop new knowledge and technologies in order to increase the life quality of society.

\section{BASIC SCIENCE, APPLIED SCIENCE, ENGINEERING SCIENCE AND TECHNOLOGY}

"Science is the "why"; it is the study of why things happen. Engineering is the "how"; engineers study how things happen and what we can do to make them better. In engineering you also gain experience in teamwork, design, and communication".

Basic/Pure Science aims to acquire information. Basic/ pure science is composed of systematic theories and laws that try to learn, understand, explain and predict nature, events and phenomena.

Applied science is also composed of theoretic (systematic) constructs; however, it is aimed more at the application. Applied science is the restructuring of basic science with the purpose of application. Basic science is the sine qua non for the applied science.

Engineering Science is regulated in order to make an artificial object meet the requirements of the applied science. It is difficult to make a clear distinction between the applied science and engineering science.

Technology is not only processing theory, at the same time technology is the path and tool of the making process. Technology is the activity of producing artifact objects. Technology covers a large spectrum of skills and techniques from religious techniques to sport or health techniques.

In the field of science, activities follows such a sequence: basic science, applied science, engineering science and technology.

\section{HISTORY OF ENGINEERING}

At the beginning of the $20^{\text {th }}$ century, especially with the study of G. Sarton, history of science has gained a scientific identity. History of the engineering field has also had a short history. There are almost no resources on this subject.

History of technology examines the changes arising from the techniques of economic, cultural and military; and it also examines the consequences of these changes in society, economy and politics. In order to understand the history of technology, historians must consider not only the tools and techniques, but also the basics of technology evolution such as the role of technology experts and engineers, their status and education, geography and climate, division of labor, invention and innovation (renewal) processes, contribution of knowledge, technical results of the research, the relationship between the technology and science, and advancements in the art customs and handcrafts.

The history of technology starts with the use of stone tools. History of the technology field is divided into four major periods: the Paleolithic (Old Stone Age) period which started approximately 2.5 million years ago. The Neolithic (New Stone Age) period which began around 9000 BC. Agricultural civilization begins with the invention of the plow in $4000 \mathrm{BC}$. The Industrial civilization covers only the last 250 years. These periodical divisions are sometimes approximate, schematic and do overlap with each other. Even today agricultural and industrial civilizations are available at the same time, and each has a partnership with the technology. In fact, today there are still isolated groups of people who are still using Stone Age Technology. Primitive forms of agriculture such as those developed in the Paleolithic period can still be found today. This period was characterized by hunting and gathering, similar to what we consider Horticulture.

In Mesopotamia, between the rivers Tigris and Euphrates, the Assyrians and the Babylonians constructed buildings and water structures in 2500 BC. They built temples and pyramids that had a height of $23 \mathrm{~m}$. In order to build these structures, they used sun-dried bricks.

In 3,000 BC, Egyptians built royal tombs with stones that ranged from 2.5 to 30 tons of continuous curved weights. The maximum height of these buildings reached as tall as $152 \mathrm{~m}$.

Mesopotamians had a large amount of mud and sun. The- 
refore, they used sun-dried bricks as a building material. In the $600 \mathrm{~s} \mathrm{BC}$, the Greeks built elegant buildings with the help of mathematics and theoretical sciences.

Engineers in the Ancient world ( $7^{\text {th }}$ century BC to AD 476) were Romans engineers. In the $400 \mathrm{~s} \mathrm{BC}$, the Romans built aqueducts, bridges and roads. The Roman's scientific contribution to engineering is negligible. Roman engineers contributed to engineering by creating consciousness of productivity, functionality and cost. They widely used semi-circular arch structures. Unlike the Greeks, Romans were the people that used technological applications rather than invented the technology themselves. They had abundant labor force (because they had slaves), materials and simple principles of construct (Londels, 2000).

In France, Poytechnique Ecole was opened in 1794. In 1802, engineering education was started at West Point Military Academy, which was the first university that launched an engineering education in the USA. Engineering was divided into two expertise groups: Military Engineers and Civilian Engineers. Society of Civil Engineers, Society of Mechanical Engineers, Institute of Industrial Engineers, Institute of Electrical and Electronics Engineers, and Institute of Chemical Engineers were opened respectively in 1818, 1847, 1880, 1884 and 1908 .

Some historians of technology believe that the Renaissance was the starting point of the continuous technical invention capacity of the western culture (Pacey, 1992).

\section{TECHNOLOGY AND ENGINEERING}

Existents are founded by three types of existence: existence in thought, existence in language, existence in external world (Çotuksöken, 1995). Any kind of existence in general can be positioned with one of these. This positioning can help clear understanding of existential.

Any existence has a concept. The concept itself is an existent. That is to say, the concept exists in the thought. "The concept is a thought framework for the meaning of the existent. This concept is the base to understand the existents. In the physical world, the concepts of existence come after the existents themselves. However, the concept of existence of cultural objects, products of the power of human creativity comes before the existents (Çotuksöken 1995). For example, a pen is an object made by human being was conceptually created in the mind of the designer and then physically brought into existence. This clearly explains the meaning of creativity (engine) in the concept of engineering. The concept becomes the ter$\mathrm{ms}$ in language.

The concept is the main condition to know existence. The concepts are conveyed from human to human through language. The concepts lie in thought for existence in language for communication. The terms are the indicators (words) of concepts in language. The background information provided above is intended to introduce the rea- ders to the concept of technology. In order to be able to comprehend the real meaning of things, it is essential to know the things and the concepts that are the fundamental baseline for this. In order to comprehend the concept of technology in its fullest meaning, it is essential to know its most fundamental principals and concepts (Günay, 2017).

"Whatever has an effect as its consequence is called a cause" (Krell, 1976). Something is called the "cause" when a consequence is achieved through a tool with its own purpose. The Cause is responsible for the consequences, and the consequences belong to the cause. Being responsible means encouraging for coming forward. Since Aristotle, there are four causes of an existence in philosophy (Krell, 1976; Heidegger, 1998a). They are: (1) the causa materialis, the material, the matter out of which, for example, a silver chalice is made; (2) the causa formalis, the form, the shape into which the material enters; (3) the causa finalis, the end, for example, sacrificial rite in relation to which the chalice required is determined as to its form and matter; (4) the causa efficiens, which brings about the effect that is the finished, actual chalice, in this case, the silversmith (Krell, 1976).

"Cause", as we say or the "causa" as Romans say, is called "Aition" by the Greeks. Aition is something that is the reason for creating another thing. Silver is something that a chalice is made of. Silver (material=hyle) is responsible for the chalice together with other causes. The chalice owns its existence to silver. The chalice also owns its existence to its shape and is limited to be used in a sacrificial rite.

To draw a borderline is to identify the borders that wrap all around. Something that wraps around is called telos and is translated as goal. Silver, form, tels (goal) are brought together by the silver master (causa efficiens). Four causes are responsible for the silver chalice to be ready for its use in collecting the donations. Four attributes of responsibility lead an object to appear, coming into existence out of nonexistence. Any means to transfer a non-existent into an existence is called "poiesis". The poiesis is not only hand-based manufacturing, or not only an art/poetical appearance based on mental activity. Physis is also a revelation.

The basis of existence is, according to Aristotle, its essence or substance (Aristoteles, 1996). There is an essence to any existence and it is formulated as an essence of form and material. Plato called the essence of a thing an "idea". Aristotle called the essence a "form" instead of an "idea". According to Plato, the "idea" is separated from the beings and stays in the world of ideas. They are real beings in the world of idea. The beings in this world are the copies of the beings in the world of ideas. Aristotle, on the other hand, does not separate ideas from the beings and is immanent to existence. The following formula is generated in order to make the concept of essence of Aristotle clear substance (ousia), essence (eidos/form), and material (hyle). 
English: Substance $=$ Essence + Material

Greek: $\quad$ Ousia $=$ Form $($ eidos $=$ idea $)+$ Hyle

This formula may help in understanding the meaning of technology. Here, technology is replaced with the positive (+) sign (Günay, 2017).

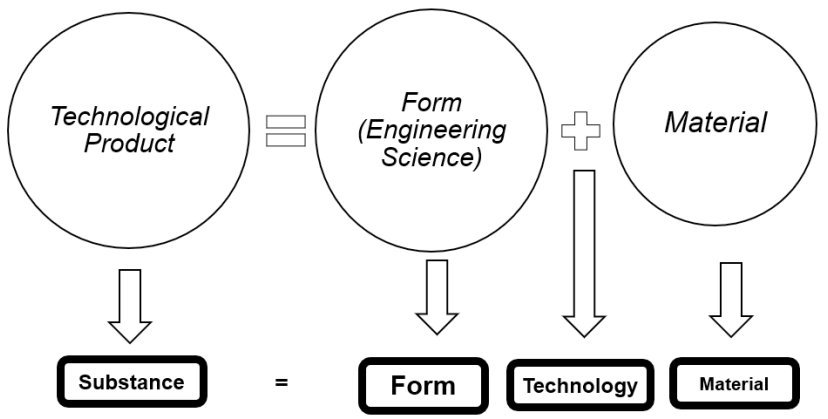

Figure 1: Technological Product and Engineering Science

Whatever the cause of merging engineering, science and material such as machine, equipment, knowledge, action etc. belongs to technology. Through technology, material is put into the shape created by engineering science. The form in the conceptual world is merged with the material in the physical world in order to create a technological product. This clearly makes Heidegger's statement "technology is to reveal" understandable. That is, a conceptual form is turned into a physical appearance and revealed through technology (Günay, 2017).

For example, consider a tea glass. The form the glass is its essence. Glass material is put into the form of a glass. The form and material can not be separated in the physical world; but can be done so in thought (Luce, 1992). When the glass is broken, the shape disappears and becomes a bulk of material glass. A material becomes glass when the material is put into the form of glass. For example, a glass rug and tea glass are both made of glass, they are different in form. Their essence and form define their identity. This implies that the form is the essence of the things.

Tekhne (technic) means art and/or craft in Greek. Technology on the other hand, is the combination of the words tekhne, and logia which means "science". What kind of existence is a technology product and where is it? Consider an automobile (Automobile $=$ Form + Material). In order to produce an automobile, automotive materials should be put into the form of an automobile. In other words, the shape of automobile should be dressed up onto the material. This necessitates technology. Technology defines how to shape the form of an automobile and the respective knowledge. Manufacturing means giving it the proper form. In terms of knowledge, the technology is existent in the language. A technological product, for instance an automobile, is existent in the external world. The form of technological product is the science, or engineering science. The automobile is designed with scientific knowledge (mechanic and thermodynamic etc.) The knowledge to put the material into the shape of an automobile is technology (Günay, 2017).
There is a very famous Ezop Tale implying the importance of the needs in technological developments. Once upon a time, a crow, in desperate need of water, comes across an ewer with a small amount of water. The crow some how manages to put its head into ewer and tries to drink the water but cannot because of its short beak. It then tries to knock down the ewer to get the water. Since the ewer is so heavy, the crow can not manage to do so. While it intends to give it up, suddenly a bright idea strikes. It fills the ewer with some small stones so that the water comes to higher level inside. Thus, the crow manages to drink the water and saves his life. The belief in "the needs fostering the efforts" in this way usually becomes the main explanation of technological effectiveness (Basalla, 1996).

Scientific knowledge is in the thought of scientists and therefore exists in realm of thought. A mathematicians works in the domain of mathematical concepts of ideal objects. Natural scientist work mainly in the area of concepts. The output of the scientists is the written material which exists in the language. However, an engineer is different. An engineer uses the concepts from science and technology (existent in thought), technological, manufacturing process and production project (existent in language) and material (existent in external world). The final product of technology is an object. Engineer performs in these three worlds (thought, language, and external world).

A scientist does not interfere with the external world but investigates and studies it. In natural science or social science, working in the same manner as in natural sciences, the scientists observe and conduct experiments. No intention to impose a form to the external world; but rather, they try to understand and explain. Traditional positivist philosophy tries to explain this phenomenon. Traditional historical philosophy tries to understand the phenomenon. As a result, scientific concepts (existed in thought) are produced and they are written down in order to record them and convey them to others. Engineers, on the other hand, as any kind of cultural objects crafted by humans, first start with the concepts for the product in the mind and produces/creates the technology product to exist in the external world (Günay, 2017).

The concepts of philosophy and science in Antic Greek, were not as clearly outlined and set up as they are today. Until the $19^{\text {th }}$ century, they are both used together. Plato used "episteme" as the knowledge of ideas or the knowledge obtained out of the experience of the known (Luce, 1992; Tiles\&Tiles, 1993).

Plato explains the difference between "doxa" an "episteme" as follows. If anybody tries to describe the road to a city for which he/she never been to, the knowledge provided is called "doxa". But if he/she describes the road after being to city and seeing it, the knowledge then becomes "episteme". The definition of Hakk-el Yakin (knowledge will full awareness) of Gazali seems to resemble "episte$m e "$. 
It is understandable to use the "episteme" and "tekhne" as in the same meaning as used by Plato in the sense of one having the knowledge through personal experience rather than knowing through a master's knowledge (Tiles and Tiles 1993). "Tekhne" is the knowledge obtained after an action. That is why "tekhne" and "episteme" are compatible (relevant) according to the knowledge based on personal experiments.

Aristotle, student of Plato, differentiated "tekhne" from "episteme" in order to put the logic into a formal structure. He used tekhne as the knowledge for building the things, for instance building a temple, or flute whereas the episteme for the knowledge obtained through reasoning and proofing.

Technic (or technology), is poiesis which is to make exist or reveal. It is not only poiesis but also able to reveal artistic-poetical appearance. Physis is the poiesis which is to emerge naturally without any intervention of human being. An example of physis is something like getting the bloom of a flower (Heidegger, 1998a). Making a flute is a poiesis. For technic becoming poiesis it is due to the realization of a concept which existed in the thought of an artist or craftsman as the products or objects existed in the external world using the technology. Poiesis is to be created by man. Physis is to become revealed naturally without any human intervention.

We consider technology as knowledge. It is the knowledge which is the basic requirements of production and construction of things. Technological product is existent in three areas of existence: in concept, language, external world. In philosophy, excellent beings are considered to have existed in all three areas. Based on this, would it be possible to claim that the importance of technology comes from the its ontologic base lies in the category of excellent beings? We refer to technology as production of knowledge, production tools, and products all together.

Before the industrial revolution, when theoretical life (bios theoretikos) - only the life of observers - prevailed (Heidegger, 1998b), technic and science were treated as different. Technic was not founded on sciences. Modern technic relies on modern natural sciences. However, it should be noted that technology did not start to rely upon the modern science with the Modern Science Revolution in the 17th century; rather, Science and Technology were intertwined during the Industrial Revolution and later (after 1760), especially in the beginning of the $19^{\text {th }}$ century. Up to the end of the $18^{\text {th }}$ century, technological developments were well ahead of scientific developments. One of the most prominent examples of this is the discovery of the thermodynamic laws which were fundamental to steam engine development about 100 years after (in the years 1847-1851) then the commercialization of steam engines.

The first time a scientific discovery yielded a technologi- cal product was in the manufacturing of electric motors. A Danish Scientist, H.C. Oersted discovered that an electric current produces a magnetic field when passing through a conductor in 1820 . Oesrted proved that when a small string wire carrying electric current applies a force in the pin of a compass, the pin diverges.

British Physicist Michael Faraday, when hearing this, tried to create continuous electron beam diversion of the pin. Faraday was the first scientist introducing the basic principles of modern electronic engine. About 10 years after Faraday's experiments, an American physicist, Joseph Henry, invented the electronic engine (Basalla, 1996).

The prominent lifestyle of the modern world was action and production based on and called bios praktikos. The bios praktikos lifestyle transformed the technic into technology.

The knowledge context of technology before the industrial revolution is based on experimental knowledge as well as knowledge of craft and/or art. The form of technology after the industrial revolution, the so called modern technology, is engineering science when science and engineering are taken into account. As stated above, technology is the means through which the concepts such as the plan of a house designed by an architect is revealed in its physical existence in the world. Another meaning of "reveal" is to differentiate modern technology and pre-modern technology. Traditional technology relied upon nature. Modern technology, on the other hand, forces nature to rely upon technology. The secrets and essence of the nature is revealed in order to get maximum benefit out of it. Note that, the hens do not lay eggs by themselves in modern farms but they are in fact forced to lay eggs. The hens are forced to live day and nights under the lighted up environments in coops and fed by production materials (water and feed) for the sake of maximum productivity. They are considered to be like an assigned egg producing machines (Heidegger, 1998a).

\section{ENGINEERING EDUCATION AND TRENDS}

Nowadays, the need of specialized skills in green innovation has been increasing (Kolmos, 2011). Universities are required to give their graduates the skills needed to contribute and compete in the business world. Countries formulate innovation strategies with governments, universities and within the business world. Innovation and entrepreneurship have become very important concepts especially for those with an engineering education. The development of creative, innovative and entrepreneur skills has become important for graduates of engineering programs. In higher education, formulating programs based on learning outcomes and student-centered education came into force.

There is a need for increasingly more complex, authoritative and systematic information. Inter-disciplinary, 
multi-disciplinary programs are in high demand. Problem-based and project-based learning (PBL) are among the innovative learning methods currently being used (Kolmos, 2011). Internationally determined criteria and measurements have become important in higher education. As information technologies and globalization became more prevalent, international trends such as international student mobility, international joint programs, consideration for pre-requisite knowledge have gained more prominence. Meanwhile, increased global competition inevitably brought the worldwide ranking of universities and programs, quality assurance and studies carried out to become the center of attraction have gained importance because of competition (King, 2007; Röpke, 1998; Tryggvason\&Apelian, 2006).

Due to the facilities brought about by internet technology, developments continue to bring the world into a university with distance education. Information and communication technologies have changed our perception of the world in a way that can never return. New methods, new requirements and needed learning outcomes have forced the change of curricula (Beerkens, 2008; Duderstadt, 2008).

Engineering is more related with how to do something and knowledge. Knowledge of how contains making knowledge and tacit knowledge. There can be some failures during the transition from theory to practice due to the deficit of tacit knowledge.

\section{CONCLUSION}

In this study, the concepts of engineering, engineer, science, basic science, applied science, engineering science and technology were discussed philosophically. Particularly, the concept of technology was tried to be clarified since technology has always been a difficult concept to understand and express exactly what it is. Here one simple formula was generated in order to show the relationships between substance (ousia), essence (eidos/form), and material (hyle) in philosophy by taking advantage of the philosophy of Aristotle. Thus, we tried to put forward a new explanation style by showing the relation between technological product, engineering science and material to understand easily what technology is. Moreover, we tried to display the relationships and limits between these concepts related with engineering field.

\section{REFERENCES}

Adams, J. L. (1995). Bir mühendisin dünyası. (C. Soydemir, Trans.). Ankara: The Scientific and Technological Research Council of Turkey.
Aristoteles (1996). Metafizik. (A. Arslan, Trans.). Istanbul, Turkey: Sosyal Publications.

Basalla, G. (1996). Teknolojinin evrimi. (C. Soydemir, Trans.). Ankara: The Scientific and Technological Research Council of Turkey.

Beerkens, E. (2008). University policies for the knowledge society: Global standardization, local reinvention. Perspectives on Global Development and Technology, 7(1), 15-31.

Çotuksöken, B. (1995). Felsefeyi anlamak ve felsefe ile anlamak. Istanbul: Kabalcı Publisher.

Duderstadt, J. J. (2008). Engineering for a changing world: A roadmap to the future of engineering practice, research and education. Michigan: The University of Michigan.

Gimpel, J. (1997). Orta çağda endüstri devrimi. (N. Özaydın, Trans.). Ankara: The Scientific and Technological Research Council of Turkey.

Günay, D. (2017). Teknoloji nedir? Felsefi bir yaklaşım. Yükseköğretim ve Bilim Dergisi, 7(1), 163-166.

Heidegger, M. (1998a). Tekniğe ilişkin soruşturma. (Ö. Doğan, Trans.). İstanbul: Paradigma Publications.

Heidegger, M. (1998b). Bilim üzerine iki ders. (H. Hünler, Trans.). Istanbul: Paradigma Publications.

Ibn Manzur (n.d.). Ebu'l-Fadl Cemaleddin Muhammed b. Mukrim el-Efriki, Lisanu'I-Arab. XIII. Beyrut: Daru's-Sadr.

King, J. E. (2007). Educating engineers for the 21st century. London: The Royal Academy of Engineering.

Kolmos, A. (2011, November 24-25). New trends in engineering education: Mega projects and globalization. Proceedings of the $1^{\text {st }}$ EUCEET Association Conference, Patras. Retrieved from http://www.euceet.upatras.gr/Content/Uploads/Abstract\%20Proceedings.pdf.

Krell, D. F. (1976). Martin Heidegger basic writings. London: Harper \& Row Publisher.

Londels, J. G. (2000). Eski Yunan ve Roma'da mühendislik. (B. Bıçakçı, Trans.). Ankara: The Scientific and Technological Research Council of Turkey.

Luce, J. V. (1992). Greek philosophy. London: Thames and Hudson.

Pacey, A. (1992). The maze of ingenuity. Massachusetts: The MIT Press.

Röpke, J. (1998). The entrepreneurial university, innovation, academic knowledge creation and regional development in a globalized economy. Germany: Philipps-Universitat Marburg.

Tiles M.\&Tiles, J. (1993). An introduction to historical epistemology. Londra: Blackwel.

Tryggvason, G.\&Apelian, D. (2006). Re-engineering engineering education for the challenges of the 21st century. The Journal of the Minerals, Metals \& Materials Society, 58(10), 14-17. 